\title{
Nursery Fertilizer Application Increases Rice Growth and Yield in Rainfed Lowlands with or without Post-Transplanting Crop Stress
}

\author{
Chhay Ros ${ }^{1}$, Peter F. White ${ }^{2}$, Richard W. Bell ${ }^{*}$ \\ ${ }^{1}$ Department of Foreign Affairs and Trade, Australian Embassy, Phnom Penh, Cambodia \\ ${ }^{2}$ Department of Agriculture and Food WA, Baron-Hay Court, S. Perth, Australia \\ ${ }^{3}$ School of Veterinary and Life Sciences, Murdoch University, Murdoch, Australia \\ Email: ${ }^{*}$ R.Bell@murdoch.edu.au
}

Received 16 June 2015; accepted 16 November 2015; accepted 23 November 2015

Copyright @ 2015 by authors and Scientific Research Publishing Inc.

This work is licensed under the Creative Commons Attribution International License (CC BY). http://creativecommons.org/licenses/by/4.0/

\section{Abstract}

In rainfed lowlands, the beneficial effects on rice (Oryza sativa) yield from fertilizing the seedling nursery may depend on the occurrence of water and nutrient stress after transplanting into the mainfield. The aim of the study was to test the effect of seedling age and nursery fertilisation on rice yield when plants experienced nutrient and water stress regimes after transplanting. The first experiment, conducted during the wet season in a low-fertility rainfed lowland field in south-east Cambodia, examined the effect of three levels of nitrogen (N), phosphorus (P) and cow manure (CM) application to the nursery and three ages of seedlings at transplanting $(4,6$ and 9 weeks after sowing: WAS) on the growth of a traditional photoperiod-sensitive rice cultivar. Increasing fertilizer application to the nursery increased shoot dry weight and grain yield at each age of seedling transplanted. Shoot dry weight and grain yield from seedlings transplanted 6 WAS were $20 \%$ and $10 \%$ higher than those from the seedlings transplanted at the other ages. Seedlings transplanted at 4 WAS, which experienced a temporary submergence for 3 days after transplanting, recorded $5 \%$ greater seedling mortality from the unfertilized than fertilized nursery soil. The taller seedlings transplanted at 6 WAS experienced less mortality despite more severe submergence. The second experiment was conducted at seven rainfed lowland sites across Cambodia to test the benefit of $\mathbf{N}$ alone and $\mathrm{N}+\mathrm{P}$ application to the nursery on rice yields in farmers' fields. In four out of seven trials, grain yield increases averaged $13 \%$ with $\mathrm{N}+\mathrm{P}$ applied to the nursery whereas $\mathrm{N}$ alone increased grain yield at two sites and depressed yield at two. Overall, fertilizer application in the nursery produced more vigorous seedlings with higher nutrient concentration which survived submer-

"Corresponding author.

How to cite this paper: Ros, C., White, P.F. and Bell, R.W. (2015) Nursery Fertilizer Application Increases Rice Growth and Yield in Rainfed Lowlands with or without Post-Transplanting Crop Stress. American Journal of Plant Sciences, 6, $2878-2892$. http://dx.doi.org/10.4236/ajps.2015.618285 
gence and grew better with or without drought or nutrient stress after transplanting, leading to increased yields of rice. The beneficial effect of nursery fertilizer was additional to any obtained by fertilizer applied to the main field at or after transplanting.

\author{
Keywords
}

Nutrient Uptake, Seedling Age, Seedling Vigor, Submergence

\title{
1. Introduction
}

About 15\% of the rainfed lowland rice fields in South and Southeast Asia can experience both drought and submergence during the growing season but in Cambodia up to $57 \%$ of paddy fields experience both these stresses [1]. Large areas of rainfed lowlands in the lower Mekong basin also have low soil fertility on account of the prevalence of sandy surface horizons [2]. Hence, rice crops in this region may encounter multiple stresses after transplanting. The extent to which nursery fertiliser application to increase seedling vigour can alleviate these stresses and enhance rice production in the main field has not been examined. In a prior glasshouse study, we reported that increased seedling vigour imposed by root pruning, leaf clipping or seedling submergence treatments did not enhance post-transplanting growth under water or nutrient stress [3]. However, the effect of seedling vigour on tolerance of rice in the field to post-transplanting stresses that are common in the low fertility, submergence- and drought-prone rainfed lowlands has not been assessed.

In order to produce more vigorous rice seedlings, farmers in Cambodia apply fertilizers, especially cow manure, to the nursery [4]. Furthermore, rice grain yield in pots was increased $10 \%$ by applying $\mathrm{N}$ and $\mathrm{P}$ to the nursery and this effect could not be replaced by increasing fertilizer application after transplanting [5]. An increase in grain yield by nursery fertilizer application may be related to increased nutrient content or to increased vigor of the seedlings that are transplanted. Either of these improvements in seedling growth may enhance posttransplanting tolerance to low main field soil nutrient status or to crop stress (e.g. drought, submergence).

In the rainfed lowlands, the age at which seedlings are transplanted can also be varied, depending on the seasonal rainfall [6]. The age of seedlings at transplanting in Cambodia ranges from as young as three weeks to as old as three months. Seedlings of advanced age may behave differently in their response to nursery fertilizer application and to post-transplanting stress. Adhikari et al. reported that transplanting 40-day-old rice seedlings increased rice yield and effective tiller number in the monsoon season compared to 20-day-old rice seedlings on a loamy, moderately fertile soil in Nepal [7]. By contrast, a number of recent studies, spurred by the interest in the system for rice intensification (SRI), have found increased post-transplanting rice yield from seedlings as young as 10 days compared to those 20 - 40 days old [8].

The present experiment was designed to examine the effect of applying fertilizer to the nursery on the grain yield of transplanted rice under water or nutrient stress after transplanting seedlings of various ages. The hypothesis was that the benefits from fertilizing the nursery were related to larger and more vigorous seedlings better able to withstand submergence, drought or nutrient stress.

\section{Materials and Methods}

\subsection{Experiment 1}

The experiment was conducted on a farmer's field $20 \mathrm{~km}$ south-west of Phnom Penh in the wet season. Soil in the mainfield was a sandy-loam with $\mathrm{pH}\left(\mathrm{H}_{2} \mathrm{O}\right)$ of $6.3,0.23 \%$ organic carbon, $0.026 \%$ total nitrogen, $1 \mathrm{mg}$ Olsen-extractable $\mathrm{P} / \mathrm{kg}$ and and cation exchange capacity of $1.4 \mathrm{cmol} / \mathrm{kg}$. The soil is classified as a Plinthustalf and belongs to the locally known Prateah Lang Soil Group [9].

Treatments were applied separately to the nursery and the main field. The nursery was laid out in a randomized complete block design with four replications and three treatments; nil (NF0), $20 \mathrm{t}$ of cow manure per ha (NF1), and $20 \mathrm{t}$ of cow manure per ha plus $60 \mathrm{~kg}$ of $\mathrm{N}$ per ha and $45 \mathrm{~kg}$ of P per ha (NF2), giving a total of 12 plots. Nursery plots $7 \times 6 \mathrm{~m}$ were separated with bunds. The plots were subdivided into three unbunded subplots representing three ages of seedlings at transplanting. Seedlings were transplanted 4, 6 or 9 weeks after sowing 
(WAS). All nursery plots received supplemental fertilizers consisting of $\mathrm{H}_{3} \mathrm{BO}_{3}(0.5 \mathrm{~kg} \mathrm{~B} / \mathrm{ha}), \mathrm{MgCl}_{2}(1 \mathrm{~kg} \mathrm{Mg} /$ ha), and $\mathrm{KCl}(30 \mathrm{~kg} \mathrm{~K} / \mathrm{ha})$.

Treatments were also imposed on plants in the main field after transplanting. Two levels of NPK (nil; $60 \mathrm{~kg} \mathrm{~N} /$ ha as urea, $40 \mathrm{~kg} \mathrm{P} / \mathrm{ha}$ as triple super phosphate, $30 \mathrm{~kg} \mathrm{~K} / \mathrm{ha}$ as potassium chloride) and two water supply regimes (drainage of free-standing water and retention of free-standing water) were applied to the main field. The combination of main field and nursery treatments resulted in 36 treatments and four replicates of each. The main field had a complete randomized block design and plot size was $4 \times 4 \mathrm{~m}$ of which $9 \mathrm{~m}^{2}$ in the center of the plot was harvested. Main field plots were separated by bunds.

For the nursery treatments, cow manure, urea and triple superphosphate and supplemental fertilizers were applied a day before sowing and incorporated into the soil by manual hoeing. Seeds of rice cv. Chhmar Laeat, a medium maturing photoperiod-sensitive cultivar, were pre-germinated by soaking overnight then incubated for $24 \mathrm{~h}$. Pre-germinated seeds were broadcast in nurseries at a rate of $50 \mathrm{~g}$ of dry seed per $\mathrm{m}^{2}$. The seeds were protected from birds by covering the whole nursery with netting. Nursery plots were maintained wet without standing water during the first week after sowing. Thereafter, water was maintained $15-20 \mathrm{~cm}$ deep by irrigation or drainage as necessary.

Seedlings in appropriate treatments were pulled and bundled one day before each time of transplanting. Only seedlings in the center of the plot were used for transplanting. Seedling bundles were then, according to normal farmers' practice, stored overnight with roots standing in water in nursery plots.

Half of the $\mathrm{N}$ (urea) and all the P (triple superphosphate) and $\mathrm{K}(\mathrm{KCl})$ was broadcast and then incorporated into the main field plots by hoeing a day before transplanting. The rest of $\mathrm{N}$ was broadcast at panicle initiation (PI). Three seedlings were transplanted per hill. Spacing between hills was 20 by $20 \mathrm{~cm}$. A week after transplanting, missing or dead hills were counted in each plot to determine plant mortality and then replanted with spare seedlings from the same nursery plot.

Water treatments were imposed immediately after transplanting. The adequate water level was imposed by maintaining free-standing water $(0-30 \mathrm{~cm}$ depth) until week 18 (Figure 1). Irrigation water was supplied or rainwater drained as necessary. The drained treatment had repeated drainage of free-standing water from the plots after rainfall events. Plots were kept free of standing water except for periods up to week 10, when heavy rain caused flooding and plots were unable to be fully drained.

Immediately before pulling at 4, 6 or 9 WAS, seedling height, leaf number and tiller number were measured in the nursery and root samples were taken from nurseries by carefully digging up the roots and washing them free from soil. A further 15 seedlings were sampled for dry matter determination. Shoot and roots were separated and samples were dried $\left(70^{\circ} \mathrm{C}\right)$, chopped, ground and then sub-sampled for analysis of $\mathrm{N}, \mathrm{P}$ and $\mathrm{K}$.

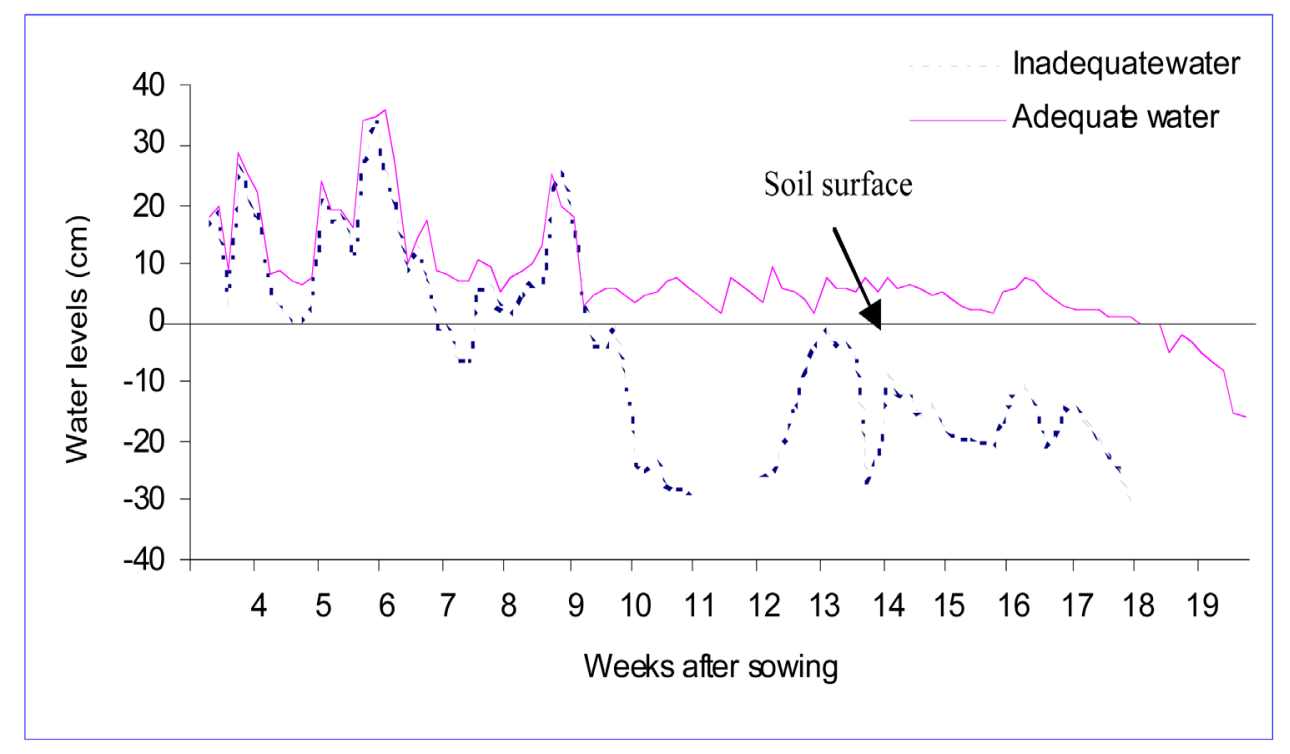

Figure 1. Perched water table level in soil of the experiment site in water adequate and inadequate treatments. Experiment 1. 
In the main field, plant height and leaf number and tiller number were recorded at PI, and panicle number, grain number per panicle, straw dry matter and grain yield were recorded in the main field at maturity. Three plant samples consisting of four adjacent hills were randomly taken from outside the harvest area. Plant samples were prepared by oven drying and milling for nutrient analysis.

After transplanting, water level in the main field was measured daily in each replicate block from adequate and drained water regime plots using piezometers. The shallow piezometer penetrated only $20 \mathrm{~cm}$ below the ground surface and measured the depth of water perched above the plough layer. The deep piezometer penetrated $70 \mathrm{~cm}$ below the ground surface and measured the depth of the ground water table below the plough layer.

The experiment was laid out in a randomized complete block design and analyzed as a 4-way analysis of variance using IRRISTAT software [10]. None of the four way interactions, and few of the three way interactions were significant.

\subsection{Experiment 2}

Experimental sites were selected in farmers' rainfed lowland fields in Kampong Chhnang, Kampong Speu, Kandal, Prey Veng (2 sites), Pursat and Siem Reap Provinces of Cambodia. The soil groups were classified as Bakan at Kampong Chhnang, Kandal and one site at Prey Veng (Prey Veng 2), Prey Khmer at Siem Reap, and Prateah Lang at other experiments [9]. Seedlings were raised in nurseries with three treatments (nil; $60 \mathrm{~kg} \mathrm{~N} / \mathrm{ha}$ as urea; $60 \mathrm{~kg} \mathrm{~N} / \mathrm{ha}$ and $17 \mathrm{~kg} \mathrm{P} / \mathrm{ha}$ as di-ammonium phosphate) and then transplanted into main field plots with low (30:4.4:8.2 kg NPK/ha) or medium levels of compound NPK fertilizer (60:8.8:16.4 kg NPK/ha). Each treatment combination was replicated five times. All $\mathrm{P}$ and $\mathrm{K}$ was applied to main fields at transplanting as triple superphosphate and $\mathrm{KCl}$. Nitrogen as urea was split between transplanting (40\%), 30 days after transplanting (30\%) and PI (30\%). Dry matter of seedlings before transplanting was determined in nursery plots. In the main field, shoot dry matter was determined at panicle initiation and grain yield at maturity. All these assessments were based on sampling from three $2 \times 2$ m quadrats per plot

The experiment was analyzed as a 2-way analysis of variance with five replicates for each site [10].

\section{Results}

\subsection{Experiment 1}

\subsubsection{Seedling Growth before Transplanting}

At 4 weeks after sowing (WAS), application of cow manure (CM) to the nursery increased seedling height, leaf number, and root dry matter by $8 \%, 25 \%$ and $40 \%$, respectively (Table 1 ). It also increased $\mathrm{P}$ and $\mathrm{K}$ concentration in seedling shoots (Table 1), but had no effect on tiller number and seedling shoot dry matter or $\mathrm{N}$ concentration. Adding both CM and inorganic fertilizer further increased plant height and leaf number by about $28 \%$, and root and shoot dry matter by $60 \%$ and $13 \%$, respectively, but had no effect on $\mathrm{N}$ and $\mathrm{P}$ concentrations compared with the CM treatment (Table 1).

At 6 WAS, CM continued to increase leaf number, and root dry matter: it also strongly increased shoot and root dry matter but had no significant effect on seedling height (Table 1). Cow manure increased N, P and $\mathrm{K}$ concentration in shoots (Table 1) but $\mathrm{P}$ and $\mathrm{K}$ increased to a lesser degree than for plants at 4 WAS. Combined application of CM, N and P to the nursery further increased seedling height, shoot dry matter and root dry matter compared to CM alone, but did not increase shoot N, P or K concentration or leaf number (Table 1).

At 9 WAS, the effects of $\mathrm{CM}$ alone, or combined $\mathrm{CM}, \mathrm{N}$ and $\mathrm{P}$ application on seedling height, leaf number, and shoot and root dry matter were similar to those at 6 WAS (Table 1). By contrast, to the seedlings at 4 and 6 WAS, however, tiller number was increased with both CM alone, and combined CM, N and P application (Table 1).

With increasing age in the nursery, seedling height, root and shoot dry matter increased but $\mathrm{N}, \mathrm{P}$ and $\mathrm{K}$ concentrations in the shoots decreased (Table 1).

\subsubsection{Plant Growth after Transplanting}

Heavy rain which occurred continuously for about 4 days after transplanting seedlings aged 4 and 6 WAS, respectively caused temporary submergence of the shorter plants (Figure 1 and Figure 2). Transplants which had received fertilizer (CM with or without NP) in the nursery recovered better from transplanting shock and 
Table 1. Effect of nursery fertilizer application on plant height, leaf and tiller number, shoot and root dry matter and seedling nitrogen $(\mathrm{N})$, phosphorus $(\mathrm{P})$ and potassium $(\mathrm{K})$ concentrations at 4, 6, and 9 weeks after sowing (WAS). Values are means of four replicates.

\begin{tabular}{|c|c|c|c|c|c|c|c|c|}
\hline Nursery fertilizer & $\begin{array}{l}\text { Plant height } \\
\text { (cm) }\end{array}$ & $\begin{array}{c}\text { Leaf } \\
\text { number/plant }\end{array}$ & $\begin{array}{c}\text { Tiller } \\
\text { number/plant }\end{array}$ & $\begin{array}{l}\text { Shoot dry } \\
\text { matter } \\
\text { (mg/plant) }\end{array}$ & $\begin{array}{l}\text { Root dry } \\
\text { matter } \\
\text { (mg/plant) }\end{array}$ & N (\%) & P (\%) & K (\%) \\
\hline \multicolumn{9}{|c|}{ At 4 WAS } \\
\hline NF0 & 36 & 3.3 & 1 & 102 & 33 & 1.32 & 0.15 & 1.68 \\
\hline NF1 & 39 & 4.4 & 1 & 106 & 53 & 1.43 & 0.35 & 2.53 \\
\hline NF2 & 54 & 4.7 & 1 & 254 & 61 & 1.54 & 0.37 & 2.66 \\
\hline LSD & $3^{* *}$ & $0.4^{* *}$ & ns & $18^{* *}$ & $6^{* *}$ & ns & $0.05^{* *}$ & $0.38^{* *}$ \\
\hline \multicolumn{9}{|c|}{ At 6 WAS } \\
\hline NF0 & 46 & 3.8 & 1 & 189 & 75 & 0.73 & 0.12 & 1.53 \\
\hline NF1 & 52 & 5.0 & 1 & 273 & 100 & 0.91 & 0.27 & 1.97 \\
\hline NF2 & 82 & 5.7 & 1 & 497 & 184 & 0.96 & 0.30 & 2.06 \\
\hline LSD: & $8^{* *}$ & $0.8^{* *}$ & ns & $25^{* *}$ & $16^{* *}$ & $0.11^{* *}$ & $0.04^{* *}$ & $0.12^{* *}$ \\
\hline \multicolumn{9}{|c|}{ At 9 WAS } \\
\hline NF0 & 51 & 4.1 & 1.8 & 1519 & 942 & 0.58 & 0.11 & 1.37 \\
\hline NF1 & 64 & 5.4 & 3.2 & 2258 & 1253 & 0.85 & 0.26 & 1.46 \\
\hline NF2 & 90 & 5.5 & 4.7 & 3961 & 2979 & 0.86 & 0.30 & 1.60 \\
\hline LSD: & $18^{* *}$ & $0.6^{* *}$ & $1.3^{* *}$ & $41^{* *}$ & $23^{* *}$ & $0.18^{*}$ & $0.07^{*}$ & ns \\
\hline
\end{tabular}

${ }^{* *}=$ significant at $\mathrm{P}<0.01 ;{ }^{*}=$ significant at $\mathrm{P}<0.05 ; \mathrm{NF} 0=$ control; NF1 = $20 \mathrm{t}$ cow manure/ha; NF2 = 20 t cow manure/ha, $60 \mathrm{~kg} \mathrm{~N} / \mathrm{ha}$ and 45 $\mathrm{kg}$ P/ha.

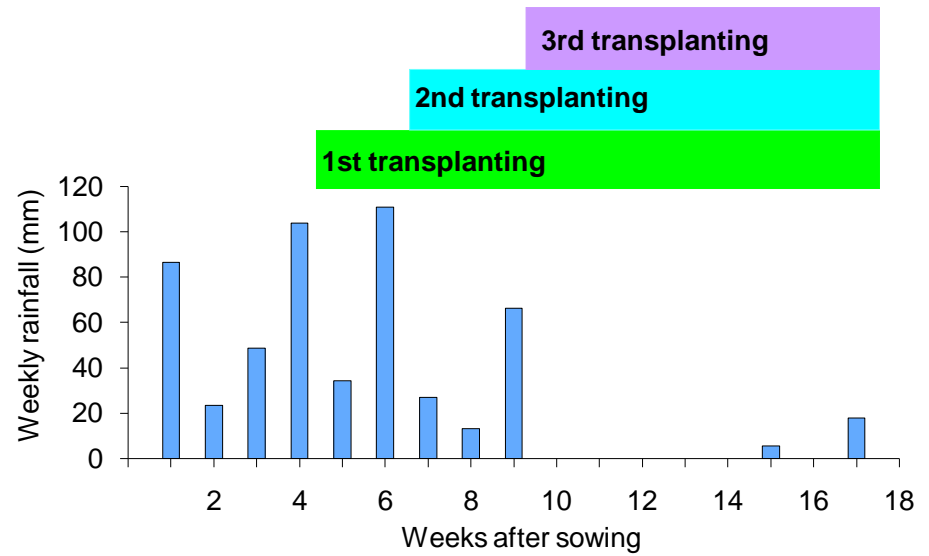

Figure 2. Weekly rainfall distribution during the experiment in relation to transplanting and harvest times. Data was collected during the wet season from Pochentong, Phnom Penh, 7 km north of the experimental site. Experiment 1.

submergence than those which had not received fertilizer. The percentage mortality of the plants 7 days after transplanting from the fertilised nursery was less than 1\% (Table 2). Mortality was greatest among seedlings transplanted at 4 WAS even though the depth of flooding was shallower than at 6 WAS (Figure 2). Replanting of missing hills was carried out a week after each transplanting so that subsequent growth responses were not confounded by differences in plant populations among plots.

In drained plots, heavy rainfall resulted in standing water for most of the first 9 weeks including the first 5 - 3 weeks of post-transplanting growth for the 4 and 6 week-old seedlings, respectively (Figure 1 and Figure 2). By contrast, for the 9 week-old seedlings water level was below the soil surface from the time of transplanting. 
Table 2. The effect of main field fertilizer application and two water regimes on tiller and leaf number, transplant mortality and shoot dry matter of rice cv. Chhmar Laeat transplanted from nurseries supplied with varying rates of fertilizer and transplanted at 4, 6 and 9 weeks after sowing (WAS). Values are means of four replicates.

\begin{tabular}{|c|c|c|c|c|c|c|c|c|c|c|c|c|}
\hline \multirow[t]{2}{*}{ Nursery fertilizer } & \multicolumn{3}{|c|}{$\begin{array}{l}\text { Tiller number } \\
\text { per hill }\end{array}$} & \multicolumn{3}{|c|}{$\begin{array}{l}\text { Leaf number } \\
\text { per hill }\end{array}$} & \multicolumn{3}{|c|}{ Transplant mortality ${ }^{\mathrm{A}}(\%)$} & \multicolumn{3}{|c|}{ Shoot dry matter ${ }^{\mathrm{B}}$ (g/hill) } \\
\hline & $\begin{array}{c}4 \\
\text { WAS }\end{array}$ & $\begin{array}{c}6 \\
\text { WAS }\end{array}$ & $\begin{array}{c}9 \\
\text { WAS }\end{array}$ & $\begin{array}{c}4 \\
\text { WAS }\end{array}$ & $\begin{array}{c}6 \\
\text { WAS }\end{array}$ & $\begin{array}{c}9 \\
\text { WAS }\end{array}$ & $\begin{array}{c}4 \\
\text { WAS }\end{array}$ & $\begin{array}{c}6 \\
\text { WAS }\end{array}$ & $\begin{array}{c}9 \\
\text { WAS }\end{array}$ & $\begin{array}{c}4 \\
\text { WAS }\end{array}$ & $\begin{array}{c}6 \\
\text { WAS }\end{array}$ & $\begin{array}{c}9 \\
\text { WAS }\end{array}$ \\
\hline \multicolumn{13}{|c|}{ Without additional NPK with drained water } \\
\hline NF0 & 7.0 & 7.4 & 2.9 & 30 & 31 & 11 & 8.1 & 3.9 & 0.2 & 4.25 & 4.99 & 2.50 \\
\hline NF1 & 7.3 & 7.2 & 3.4 & 32 & 31 & 13 & 5.0 & 0.7 & 0.1 & 6.16 & 6.03 & 3.41 \\
\hline NF2 & 6.7 & 7.6 & 3.1 & 31 & 27 & 10 & 0.9 & 0.3 & 0.1 & 6.90 & 6.35 & 3.49 \\
\hline Mean & 7.0 & 7.4 & 3.1 & 31 & 30 & 11 & 4.7 & 1.6 & 0.1 & 5.77 & 5.79 & 3.13 \\
\hline \multicolumn{13}{|c|}{ With additional NPK (60-40-30) with drained water } \\
\hline NF0 & 8.2 & 8.8 & 4.0 & 37 & 37 & 14 & 7.5 & 1.7 & 0.1 & 8.84 & 8.21 & 3.46 \\
\hline NF1 & 8.2 & 8.6 & 3.5 & 37 & 38 & 13 & 3.4 & 0.4 & 0.1 & 11.14 & 9.34 & 4.33 \\
\hline NF2 & 7.4 & 8.7 & 3.2 & 33 & 37 & 11 & 0.8 & 0.1 & 0.1 & 11.87 & 10.09 & 5.88 \\
\hline Mean & 7.9 & 8.7 & 3.6 & 36 & 37 & 13 & 3.9 & 0.7 & 0.1 & 10.62 & 9.21 & 4.56 \\
\hline \multicolumn{13}{|c|}{ Without additional NPK with adequate water supply } \\
\hline NF0 & 6.3 & 7.4 & 3.5 & 26 & 31 & 13 & 8.2 & 1.2 & 0.1 & 6.45 & 5.09 & 3.35 \\
\hline NF1 & 6.8 & 6.8 & 3.5 & 31 & 30 & 12 & 2.0 & 0.3 & 0.1 & 7.37 & 5.91 & 3.77 \\
\hline NF2 & 7.0 & 7.6 & 3.1 & 32 & 31 & 10 & 0.7 & 0.2 & 0.1 & 8.81 & 6.78 & 4.91 \\
\hline Mean & 6.7 & 7.3 & 3.4 & 30 & 31 & 12 & 3.6 & 0.6 & 0.1 & 7.54 & 5.93 & 4.01 \\
\hline \multicolumn{13}{|c|}{ With additional NPK (60-40-30) with adequate water supply } \\
\hline NF0 & 8.9 & 8.0 & 3.6 & 36 & 34 & 13 & 7.9 & 1.3 & 0.3 & 9.30 & 7.57 & 3.78 \\
\hline NF1 & 8.2 & 8.8 & 4.3 & 36 & 38 & 13 & 2.9 & 0.5 & 0.1 & 10.63 & 7.81 & 4.62 \\
\hline NF2 & 7.1 & 9.1 & 3.7 & 32 & 35 & 12 & 0.7 & 0.2 & 0.1 & 12.78 & 12.97 & 5.65 \\
\hline Mean & 8.1 & 8.6 & 3.9 & 35 & 36 & 13 & 3.8 & 0.7 & 0.2 & 10.90 & 9.45 & 4.68 \\
\hline \multicolumn{13}{|l|}{ LSD: ${ }^{\mathrm{C}}$} \\
\hline \multicolumn{2}{|l|}{ Nursery fertilizer (N) } & \multicolumn{2}{|l|}{ ns } & \multicolumn{4}{|c|}{ ns } & \multicolumn{2}{|c|}{$0.05^{* *}$} & \multicolumn{3}{|c|}{$0.10^{* *}$} \\
\hline \multicolumn{2}{|l|}{ Age of seedling (A) } & \multicolumn{2}{|l|}{$0.4^{* *}$} & \multicolumn{4}{|c|}{$1.89^{* *}$} & \multicolumn{2}{|c|}{$0.05^{* *}$} & \multicolumn{3}{|c|}{$0.10^{* *}$} \\
\hline \multicolumn{2}{|c|}{ Main field fertilizer (F) } & $0.3^{* *}$ & & \multicolumn{4}{|c|}{$1.89^{* *}$} & \multicolumn{2}{|c|}{$0.02^{* *}$} & \multicolumn{3}{|c|}{$0.08^{* *}$} \\
\hline \multicolumn{2}{|l|}{ Water regime $(\mathrm{W})$} & ns & & \multicolumn{4}{|c|}{ ns } & & & & $0.08^{* *}$ & \\
\hline $\mathrm{N} \times \mathrm{A}$ & & ns & & & & & & & & & $0.18^{* *}$ & \\
\hline $\mathrm{N} \times \mathrm{F}$ & & ns & & & & & & & & & $0.14^{* *}$ & \\
\hline $\mathrm{N} \times \mathrm{W}$ & & ns & & & & & & & & & $0.14^{* *}$ & \\
\hline $\mathrm{A} \times \mathrm{F}$ & & ns & & & & & & & & & $0.14^{* *}$ & \\
\hline $\mathrm{A} \times \mathrm{W}$ & & ns & & & & & & & & & $0.14^{* *}$ & \\
\hline $\mathrm{F} \times \mathrm{W}$ & & ns & & & & & & & & & $0.11^{* *}$ & \\
\hline CV (\%) & & 15 & & & & & & & & & 3.7 & \\
\hline
\end{tabular}

${ }^{* *}=$ significant at $1 \%$ level; ${ }^{*}=$ significant at $5 \%$ level; ns = not significant. NF0 = control; NF1 = 20 t/ha cow manure; NF2 = 20 t/ha cow manure, 60 $\mathrm{kg} / \mathrm{ha} \mathrm{N}$ and $45 \mathrm{~kg} / \mathrm{ha} \mathrm{P} .{ }^{\mathrm{A}}$ measured one week after transplanting. ${ }^{\mathrm{B}}$ Sampled at panicle initiation. ${ }^{\mathrm{C}}$ The four-way and most of the three way interactions were not significant. 


\subsubsection{Transplanting to Panicle Initiation}

At PI, shoot dry matter of the plants transplanted at 4 WAS was the highest, because these plants had grown for the longest period in the main field. Delaying the time of transplanting by 2 or 5 weeks reduced shoot dry matter at PI by $15 \%$ and $50 \%$, respectively, regardless of water supply or fertilizer application to the main field (Table 3).

Table 3. Effect of main field fertilizer application and two water regimes on nutrient concentration in the shoot of rice cv. Chhmar Laeat transplanted from nurseries supplied with varying rates of fertilizers and transplanted at 4, 6 and 9 weeks after sowing (WAS). Values are means of four replicates. Shoots sampled at panicle initiation.

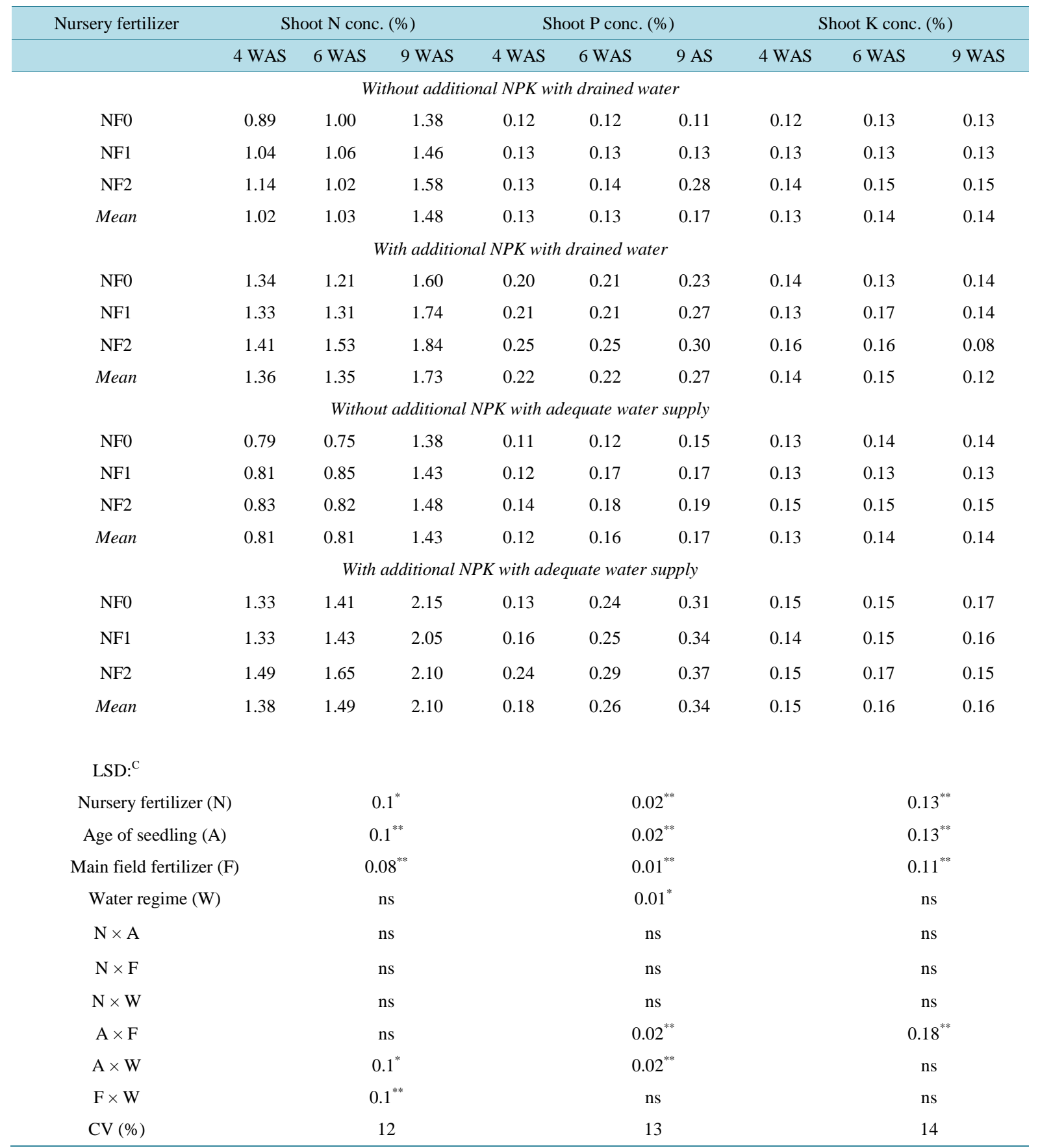

${ }^{* *}=$ significant at $1 \%$ level; ${ }^{*}=$ significant at $5 \%$ level; ns = not significant. NF0 = control; NF1 = 20 t/ha cow manure; NF2 = 20 t/ha cow manure, 60 $\mathrm{kg} / \mathrm{ha} \mathrm{N}$ and $45 \mathrm{~kg} / \mathrm{ha} \mathrm{P.}{ }^{\mathrm{C}}$ The four-way and three way interactions were not significant. 
However when CM alone was added to the nursery, shoot dry matter of plants from seedlings transplanted at 4, 6 and 9 weeks was higher than when none was applied to the nursery (Table 2). When CM, N and P were applied to the nursery, shoot dry matter of seedlings transplanted at 4, 6 and 9 WAS was even higher than the CM nursery treatment (Table 2).

Cow manure application to the nursery had no effect on $\mathrm{N}$ concentration in shoots at PI but when combined with $\mathrm{N}$ and $\mathrm{P}$ application to the nursery, $\mathrm{N}$ concentration in shoots increased by $12 \%$ and $15 \%$ when seedlings were transplanted at 4 and 6 WAS, respectively. When seedlings were transplanted at 4 and 9 WAS, P concentration in shoots at PI increased by $20 \%$ and $10 \%$, respectively, due to CM was applied to the nursery (Table 3 ). Furthermore, the combined CM and $\mathrm{N}$ and $\mathrm{P}$ fertilizer applications significantly increased the $\mathrm{P}$ concentration in shoots of plants at PI for each age at which seedlings were transplanted (Table 3).

Nursery fertilizer application increased shoot dry matter with and without main field fertilizer but the greater effects were obtained with NPK application in the main field (Table 2). Adequate water regime had the greatest positive impact on shoot dry matter when seedlings were transplanted at 4 WAS.

\subsubsection{Panicle Initiation to Harvest}

At maturity, nursery fertilizer had a positive effect on panicle number but had no effect on panicle length, 100grain weight or grain fertility (data not shown). The CM application to the nursery increased grain yield by 5\%, $12 \%$ and $4 \%$ when seedlings were transplanted at 4, 6 and 9 WAS, respectively. The application of CM, N and P to the nursery had similar effects on grain yield as the effect of CM application alone (Table 4). Straw yield increased $12 \%$ by applying CM to the nursery when seedlings were transplanted at 4 WAS but not with older transplants (Table 4).

Applying CM to the nursery increased P concentration in straw by 150\%, 80\% and $100 \%$ when seedlings were transplanted at 4, 6 and 9 WAS, respectively (Table 5). However, the CM application to the nursery increased $\mathrm{N}$ concentration in straw by $15 \%$ only when seedlings were transplanted at 9 WAS (Table 5). Combined application of CM and $\mathrm{N}$ and P, increased $\mathrm{N}$ and $\mathrm{P}$ concentrations in straw by up to $35 \%$ and $100 \%$, respectively, compared to nutrient concentrations in shoots of plants which received CM alone.

Panicle number and grain and straw yields were all lower when NPK fertilizer was not applied to the main field compared to when it was. However, the effect of nursery fertilizer application on straw yield and grain yield of plants grown without additional NPK applied to the main field was similar to that of plants which received NPK in the main field for all ages of transplanting. Grain yield increased by 10\% and 5\% with CM application in the nursery when seedlings were transplanted at 4 and 9 WAS (Table 4). Cow manure alone, in this case, increased straw yield only when seedlings were transplanted at 4 WAS but the magnitude of increase was two times higher than with NPK in the main field (Table 4).

With repeated drainage of free-standing water, the impact of nursery fertilizer application (either CM applied alone or in combination with $\mathrm{N}$ and $\mathrm{P}$ ), on shoot dry matter and grain yield were similar to the effects seen under the adequate water regime (Table 3 and Table 4). With drained water, omitting NPK from the main field decreased grain yield by $0.6-1.0 \mathrm{t} \cdot \mathrm{ha}^{-1}$. Drained water had no effect on grain yield of seedlings transplanted at 4 WAS, but depressed that of seedlings transplanted at 6 and 9 WAS. By contrast, the drainage of free-standing water had minimal effect on straw yield, or on shoot dry matter. The depression in grain yield with drainage of freee-standing water at 6 and 9 WAS was most clearly related to the decline in shoot N concentration, and was also reflected in decreased grain $\mathrm{N}$ concentration (data not shown). Furthermore, fertilizer application to the nursery had similar effect on the $\mathrm{N}$ and $\mathrm{P}$ concentration in shoots and straw as when adequate water was supplied.

Straw and grain yield of seedlings transplanted at 6 WAS were $10 \%$ and $15 \%$ higher than those of plants grown from seedlings aged 4 and 9 WAS, respectively (Table 4). Nitrogen and P concentration in shoot (Table 3 ), and $\mathrm{K}$ concentration in straw and in grain of plants grown from seedlings aged 9 WAS were greater than those in plants grown from seedlings aged 4 and 6 WAS (Table 5, grain data not shown).

\subsection{Experiment 2}

Nursery fertilizer increased dry matter of seedlings at transplanting only at Kampong Chhnang and decreased it at the Kandal (Table 6). After transplanting, shoot dry matter at PI was generally unaffected by the main field fertilizer or nursery fertilizer treatment except at Pursat and Kampong Chhnang. However, final grain yield was 
Table 4. The effect of main field fertilizer application and two water regimes on straw and grain yields of rice cv. Chhmar Laeat transplanted from nurseries supplied with varying rates of fertilizer and transplanted at 4, 6 and 9 weeks after sowing (WAS). Values are means of four replicates.

\begin{tabular}{|c|c|c|c|c|c|c|c|c|c|c|c|c|}
\hline \multirow[t]{2}{*}{ Nursery fertilizer } & \multicolumn{3}{|c|}{$\begin{array}{l}\text { Panicle number } \\
\text { per } \mathrm{m}^{2}\end{array}$} & \multicolumn{3}{|c|}{ Straw yield (t/ha) } & \multicolumn{3}{|c|}{ Grain fertility (\%) } & \multicolumn{3}{|c|}{ Grain yield (kg/ha) } \\
\hline & $\begin{array}{c}4 \\
\text { WAS }\end{array}$ & $\begin{array}{c}6 \\
\text { WAS }\end{array}$ & $\begin{array}{c}9 \\
\text { WAS }\end{array}$ & $\begin{array}{c}4 \\
\text { WAS }\end{array}$ & $\begin{array}{c}6 \\
\text { WAS }\end{array}$ & $\begin{array}{c}9 \\
\text { WAS }\end{array}$ & $\begin{array}{c}4 \\
\text { WAS }\end{array}$ & $\begin{array}{c}6 \\
\text { WAS }\end{array}$ & $\begin{array}{c}9 \\
\text { WAS }\end{array}$ & $\begin{array}{c}4 \\
\text { WAS }\end{array}$ & $\begin{array}{c}6 \\
\text { WAS }\end{array}$ & $\begin{array}{c}9 \\
\text { WAS }\end{array}$ \\
\hline \multicolumn{13}{|c|}{ Without additional NPK with drained water } \\
\hline NF0 & 323 & 350 & 309 & 1.19 & 1.72 & 1.58 & 88 & 90 & 74 & 1205 & 1292 & 1192 \\
\hline NF1 & 365 & 383 & 342 & 1.45 & 1.91 & 1.60 & 90 & 91 & 77 & 1309 & 1455 & 1287 \\
\hline NF2 & 373 & 393 & 354 & 1.62 & 1.99 & 2.06 & 91 & 89 & 80 & 1349 & 1535 & 1339 \\
\hline Mean & 354 & 375 & 335 & 1.42 & 1.88 & 1.75 & 90 & 90 & 77 & 1288 & 1427 & 1273 \\
\hline \multicolumn{13}{|c|}{ With additional NPK (60-40-30) with drained water } \\
\hline NF0 & 377 & 496 & 467 & 2.68 & 3.44 & 2.83 & 89 & 86 & 80 & 2001 & 2338 & 1811 \\
\hline NF1 & 394 & 517 & 486 & 2.73 & 3.42 & 2.96 & 91 & 86 & 83 & 2243 & 2461 & 1871 \\
\hline NF2 & 410 & 544 & 496 & 3.07 & 3.56 & 2.96 & 92 & 87 & 84 & 2394 & 2584 & 2125 \\
\hline Mean & 394 & 519 & 483 & 2.83 & 3.47 & 2.92 & 91 & 86 & 82 & 2213 & 2461 & 1936 \\
\hline \multicolumn{13}{|c|}{ Without additional NPK with adequate water supply } \\
\hline NF0 & 338 & 377 & 338 & 1.70 & 2.22 & 2.01 & 86 & 83 & 79 & 1242 & 1579 & 1292 \\
\hline NF1 & 367 & 388 & 363 & 2.20 & 2.32 & 2.04 & 87 & 88 & 81 & 1355 & 1604 & 1338 \\
\hline NF2 & 375 & 400 & 398 & 2.19 & 2.42 & 2.05 & 87 & 89 & 82 & 1397 & 1622 & 1351 \\
\hline Mean & 360 & 388 & 366 & 2.03 & 2.32 & 2.03 & 87 & 87 & 81 & 1331 & 1602 & 1327 \\
\hline \multicolumn{13}{|c|}{ With additional NPK (60-40-30) with adequate water supply } \\
\hline NF0 & 442 & 515 & 473 & 2.70 & 3.29 & 3.16 & 85 & 87 & 84 & 2168 & 2479 & 2136 \\
\hline NF1 & 459 & 523 & 502 & 3.03 & 3.23 & 3.20 & 87 & 89 & 85 & 2277 & 2771 & 2215 \\
\hline NF2 & 481 & 531 & 506 & 3.20 & 3.47 & 3.22 & 90 & 89 & 84 & 2284 & 2831 & 2300 \\
\hline Mean & 461 & 523 & 494 & 2.98 & 3.33 & 3.19 & 87 & 88 & 84 & 2243 & 2694 & 2217 \\
\hline \multicolumn{13}{|l|}{$\mathrm{LSD}^{\mathrm{C}}$} \\
\hline Nursery fertilizer (N) & & $20^{* *}$ & & & $0.11^{* *}$ & & & $3.0^{* *}$ & & & $43^{* *}$ & \\
\hline Age of seedling (A) & & $20^{* *}$ & & & $0.11^{* *}$ & & & $3.0^{* *}$ & & & $43^{* *}$ & \\
\hline Main field fertilizer (F) & & $16^{* *}$ & & & $0.09^{* *}$ & & & $2.46^{* *}$ & & & $35^{* *}$ & \\
\hline Water regime $(\mathrm{W})$ & & $16^{* *}$ & & & $0.09^{* *}$ & & & $2.46^{* *}$ & & & $35^{* *}$ & \\
\hline $\mathrm{N} \times \mathrm{A}$ & & ns & & & ns & & & $5.20^{*}$ & & & ns & \\
\hline $\mathrm{N} \times \mathrm{F}$ & & ns & & & ns & & & ns & & & $61^{* *}$ & \\
\hline $\mathrm{N} \times \mathrm{W}$ & & ns & & & ns & & & ns & & & ns & \\
\hline $\mathrm{A} \times \mathrm{F}$ & & $28^{* *}$ & & & ns & & & $4.26^{*}$ & & & $61^{* *}$ & \\
\hline $\mathrm{A} \times \mathrm{W}$ & & ns & & & ns & & & ns & & & $61^{* *}$ & \\
\hline $\mathrm{F} \times \mathrm{W}$ & & ns & & & $0.13^{* *}$ & & & ns & & & $50^{*}$ & \\
\hline CV (\%) & & 11.6 & & & 10.8 & & & 6.9 & & & 5.7 & \\
\hline
\end{tabular}

${ }^{* *}=$ significant at $1 \%$ level; ${ }^{*}=$ significant at 5\% level; ns = not significant. NF0 = control; NF1 = 20 t/ha cow manure; NF2 = 20 t/ha cow manure, 60 $\mathrm{kg} / \mathrm{ha} \mathrm{N}$ and $45 \mathrm{~kg} / \mathrm{ha} \mathrm{P}{ }^{\mathrm{C}}$ The four-way and most of the three way interactions were not significant.

increased at these sites and additionally at Kampong Speu and Siem Reap sites (Table 6). At Pursat and Siem Reap only, $\mathrm{N}+\mathrm{P}$ applied to nursery decreased days to flowering by 1 - 2 days.

At 4 sites where $\mathrm{N}+\mathrm{P}$ applied to the nursery increased grain yield, the average increase was $13 \%$. By contrast, $\mathrm{N}$ alone increased grain yield at two sites, and decreased it at 2 sites. Responses of straw dry matter at maturity were similar to those for grain yield (data not shown). 
Table 5. Effect of mainfield fertilizer application and two water regimes on nutrient concentration in the straw of rice cv. Chhmar Laeat transplanted from nurseries supplied with varying rates of fertilizers and transplanted at 4, 6 and 9 weeks after sowing (WAS). Values are means of four replicates.

\begin{tabular}{|c|c|c|c|c|c|c|c|c|c|}
\hline \multirow[b]{2}{*}{ Nursery fertilizer } & \multicolumn{3}{|c|}{ Straw N conc. (\%) } & \multicolumn{3}{|c|}{ Straw P conc. (\%) } & \multicolumn{3}{|c|}{ Straw K conc. (\%) } \\
\hline & $\begin{array}{c}4 \\
\text { WAS }\end{array}$ & $\begin{array}{c}6 \\
\text { WAS }\end{array}$ & $\begin{array}{c}9 \\
\text { WAS }\end{array}$ & $\begin{array}{c}4 \\
\text { WAS }\end{array}$ & $\begin{array}{c}6 \\
\text { WAS }\end{array}$ & $\begin{array}{c}9 \\
\text { WAS }\end{array}$ & $\begin{array}{c}4 \\
\text { WAS }\end{array}$ & $\begin{array}{c}6 \\
\text { WAS }\end{array}$ & $\begin{array}{c}9 \\
\text { WAS }\end{array}$ \\
\hline \multicolumn{10}{|c|}{ Without additional NPK with drained water } \\
\hline NF0 & 0.34 & 0.38 & 0.32 & 0.02 & 0.02 & 0.02 & 0.67 & 0.98 & 1.07 \\
\hline NF1 & 0.39 & 0.39 & 0.38 & 0.04 & 0.03 & 0.02 & 0.63 & 0.89 & 1.16 \\
\hline NF2 & 0.40 & 0.41 & 0.44 & 0.05 & 0.03 & 0.03 & 0.80 & 1.15 & 1.25 \\
\hline Mean & 0.38 & 0.39 & 0.38 & 0.04 & 0.03 & 0.02 & 0.70 & 1.01 & 1.16 \\
\hline \multicolumn{10}{|c|}{ With additional NPK (60-40-30) with drained water } \\
\hline NF0 & 0.38 & 0.40 & 0.31 & 0.09 & 0.12 & 0.05 & 0.54 & 0.79 & 1.22 \\
\hline NF1 & 0.47 & 0.41 & 0.37 & 0.12 & 0.12 & 0.09 & 0.53 & 1.12 & 1.40 \\
\hline NF2 & 0.58 & 0.48 & 0.49 & 0.14 & 0.15 & 0.12 & 0.87 & 1.38 & 2.15 \\
\hline Mean & 0.48 & 0.43 & 0.39 & 0.12 & 0.13 & 0.09 & 0.64 & 1.10 & 1.59 \\
\hline \multicolumn{10}{|c|}{ Without additional NPK with adequate water supply } \\
\hline NF0 & 0.31 & 0.35 & 0.35 & 0.03 & 0.02 & 0.03 & 0.63 & 0.82 & 0.56 \\
\hline NF1 & 0.35 & 0.37 & 0.36 & 0.05 & 0.03 & 0.03 & 0.67 & 1.17 & 0.82 \\
\hline NF2 & 0.39 & 0.35 & 0.39 & 0.07 & 0.04 & 0.04 & 0.71 & 1.38 & 1.14 \\
\hline Mean & 0.35 & 0.35 & 0.37 & 0.05 & 0.03 & 0.03 & 0.67 & 1.12 & 0.84 \\
\hline \multicolumn{10}{|c|}{ With additional NPK (60-40-30) with adequate water supply } \\
\hline NF0 & 0.42 & 0.35 & 0.42 & 0.02 & 0.05 & 0.05 & 0.54 & 1.00 & 1.21 \\
\hline NF1 & 0.43 & 0.36 & 0.49 & 0.05 & 0.09 & 0.10 & 0.65 & 1.20 & 1.45 \\
\hline NF2 & 0.50 & 0.59 & 0.51 & 0.10 & 0.12 & 0.13 & 0.99 & 1.47 & 1.56 \\
\hline Mean & 0.45 & 0.43 & 0.47 & 0.05 & 0.09 & 0.10 & 0.72 & 1.22 & 1.41 \\
\hline \multicolumn{10}{|l|}{ LSD: } \\
\hline Nursery fertilizer (N) & & $0.04^{* *}$ & & \multicolumn{4}{|c|}{$0.01^{* *}$} & \multicolumn{2}{|r|}{$0.16^{* *}$} \\
\hline Age of seedling (A) & & ns & & \multicolumn{4}{|c|}{ ns } & \multicolumn{2}{|r|}{$0.16^{* *}$} \\
\hline Main field fertilizer $(\mathrm{F})$ & & $0.03^{* *}$ & & \multicolumn{4}{|c|}{$0.01^{*}$} & \multicolumn{2}{|r|}{$0.13^{* *}$} \\
\hline Water regime (W) & & ns & & \multicolumn{4}{|c|}{ ns } & \multicolumn{2}{|r|}{ ns } \\
\hline $\mathrm{N} \times \mathrm{A}$ & & ns & & \multicolumn{4}{|c|}{ ns } & \multicolumn{2}{|r|}{ ns } \\
\hline $\mathrm{N} \times \mathrm{F}$ & & $0.05^{*}$ & & \multicolumn{4}{|c|}{$0.02^{*}$} & \multicolumn{2}{|r|}{ ns } \\
\hline $\mathrm{N} \times \mathrm{W}$ & & ns & & \multicolumn{4}{|c|}{ ns } & \multicolumn{2}{|r|}{ ns } \\
\hline $\mathrm{A} \times \mathrm{F}$ & & ns & & \multicolumn{4}{|c|}{$0.02^{* *}$} & \multicolumn{2}{|r|}{$0.23^{* *}$} \\
\hline $\mathrm{A} \times \mathrm{W}$ & & ns & & \multicolumn{4}{|c|}{$0.02^{*}$} & \multicolumn{2}{|r|}{$0.23^{*}$} \\
\hline $\mathrm{F} \times \mathrm{W}$ & & ns & & & & & & & ns \\
\hline CV (\%) & & 15 & & & & & & & 28 \\
\hline
\end{tabular}

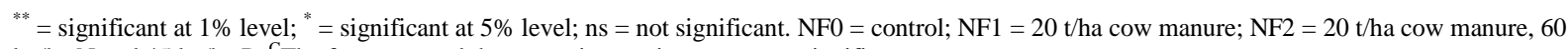
$\mathrm{kg} / \mathrm{ha} \mathrm{N}$ and $45 \mathrm{~kg} / \mathrm{ha} \mathrm{P}$. ${ }^{\mathrm{C}}$ The four-way and three way interactions were not significant. 
Table 6. Effect of nursery fertilizer application on seedling dry matter $\left(\mathrm{kg} \mathrm{DM} / \mathrm{m}^{2}\right)$ at transplanting and on the response to main field fertilizer ( - or + ) of shoot DM (t/ha) at panicle initiation (PI) and grain yield (t/ha) at maturity of rice at 7 sites in Cambodia. Values are means of five replicates. Experiment 2.

\begin{tabular}{|c|c|c|c|c|c|c|c|c|c|c|c|c|c|c|}
\hline \multirow{2}{*}{$\begin{array}{l}\text { Nursery } \\
\text { fertilizer }\end{array}$} & \multicolumn{2}{|c|}{ Kandal } & \multicolumn{2}{|c|}{ Prey Veng 1} & \multicolumn{2}{|c|}{ Prey Veng 2} & \multicolumn{2}{|c|}{ Pursat } & \multicolumn{2}{|c|}{ K. Chhnang } & \multicolumn{2}{|c|}{ K. Speu } & \multicolumn{2}{|c|}{ Siem Reap } \\
\hline & + & - & + & - & + & - & + & - & + & - & + & - & + & - \\
\hline \multicolumn{15}{|c|}{ Seedling DM } \\
\hline Nil & & 0.61 & & 1.03 & & 1.02 & & 0.38 & & 0.58 & & 0.75 & & 0.49 \\
\hline $\mathrm{N}$ & & 0.53 & & 0.98 & & 1.14 & & 0.36 & & 0.69 & & 0.74 & & 0.41 \\
\hline NP & & 0.57 & & 1.09 & & 1.10 & & 0.40 & & 0.70 & & 0.80 & & 0.44 \\
\hline $\begin{array}{c}\mathrm{P}^{\mathrm{A}} \\
\text { nursery }\end{array}$ & & 0.05 & & ns & & ns & & ns & & 0.09 & & ns & & ns \\
\hline \multicolumn{15}{|c|}{ Shoot DM at PI } \\
\hline Nil & 2.66 & 2.58 & - & - & 1.06 & 0.89 & 0.92 & 0.82 & 1.43 & 1.38 & 2.39 & 2.28 & 1.49 & 1.12 \\
\hline $\mathrm{N}$ & 2.66 & 2.49 & - & - & 1.00 & 1.01 & 0.96 & 0.80 & 1.49 & 1.29 & 2.57 & 2.29 & 1.39 & 1.54 \\
\hline NP & 2.86 & 2.71 & - & - & 1.05 & 0.96 & 1.04 & 1.06 & 1.17 & 1.65 & 2.49 & 2.55 & 1.41 & 1.42 \\
\hline $\begin{array}{c}\mathrm{P}^{\mathrm{A}} \text { main } \\
\text { field } \\
\text { nursery }\end{array}$ & & $\begin{array}{l}\text { ns } \\
\text { ns }\end{array}$ & & & & $\begin{array}{l}\text { ns } \\
\text { ns }\end{array}$ & & $\begin{array}{c}\text { ns } \\
0.02\end{array}$ & & $\begin{array}{c}\text { ns } \\
0.03\end{array}$ & & $\begin{array}{l}\text { ns } \\
\text { ns }\end{array}$ & & $\begin{array}{l}\text { ns } \\
\text { ns }\end{array}$ \\
\hline \multicolumn{15}{|c|}{ Grain yield } \\
\hline Nil & 6.2 & 5.7 & 3.1 & 2.7 & 1.4 & 1.4 & 2.5 & 2.3 & 3.3 & 2.9 & 3.3 & 3.3 & 2.9 & 2.9 \\
\hline $\mathrm{N}$ & 5.6 & 5.2 & 2.3 & 2.2 & 1.4 & 1.3 & 2.6 & 2.3 & 3.1 & 2.8 & 3.6 & 3.6 & 3.7 & 3.0 \\
\hline $\mathrm{NP}$ & 6.0 & 5.9 & 3.3 & 2.2 & 1.3 & 1.1 & 3.0 & 2.6 & 3.5 & 3.1 & 3.3 & 3.3 & 3.7 & 3.0 \\
\hline $\begin{array}{l}\mathrm{P}^{\mathrm{A}} \text { main } \\
\text { field } \\
\text { nursery }\end{array}$ & & $\begin{array}{c}\text { ns } \\
0.01\end{array}$ & & $\begin{array}{l}\text { ns } \\
\text { ns }\end{array}$ & & $\begin{array}{l}\text { ns } \\
\text { ns }\end{array}$ & & $\begin{array}{l}0.02 \\
0.01\end{array}$ & & $\begin{array}{l}0.01 \\
0.07\end{array}$ & & $\begin{array}{c}\text { ns } \\
0.1\end{array}$ & & $\begin{array}{l}0.03 \\
0.05\end{array}$ \\
\hline
\end{tabular}

${ }^{\text {A}}$ Probability of significant effects of nursery fertilizer or main field fertilizer treatments from $\mathrm{F}$ test.

\section{Discussion}

Applying fertilizer to the nursery increased final grain yield of rice under field conditions in low fertility rainfed lowland soils. The present results extend the glasshouse results reported earlier [5] by demonstrating that nursery fertilizer addition can increase yield in the field in both fertilized and unfertilized main fields. Furthermore, and importantly, the effects of low nutrient supply in the nursery were not reversed by applying higher rates of fertilizer after transplanting or by transplanting older seedlings. Similarly, Shalaby et al. [11], Rajagopalan and Krishnarajan [12] and Panda et al. [13] found that nutrient application to nurseries improved rice grain yield while Adhikari et al. [7] found no effect of nursery $\mathrm{N}$ fertiliser application on post-transplanting growth or yield of rice on a moderately fertile loamy soil in the mid-hills of Nepal.

The responses in yield to nursery fertilizer application seen in Experiment 1 are relevant to a large proportion of rice area of Cambodia because this experiment is conducted on the Prateah Lang soil which accounts for 35\% of the rice soils of Cambodia [9]. Low fertility sandy lowland rainfed soils occur in northeast Thailand and Laos [2], and the present results have relevance to those rice-growing areas as well. As the lack of response to nursery fertiliser application in Nepal shows, the present results may not be relevant where there is a higher inherent fertility of the nursery soils [7]. The fact that the responses to nursery fertilizer application occurred regardless of water regime, and with or without basal fertilizer applied at transplanting, further supports the notion that this finding may have wide practical significance for rice cultivation in rainfed lowlands. Indeed when the effects of fertilizer application on the nursery were tested in a wider range of soils and environments in Experiment 2, grain yield increases were obtained at 4 out 7 sites with $\mathrm{N}+\mathrm{P}$, and none of them showed a negative effect of $\mathrm{N}+\mathrm{P}$ applied to the nursery. At responsive sites the average relative yield increase was $13 \%$. By contrast, $\mathrm{N}$ alone had mixed effects, producing negative effects on yield as often as positive effects. The variable response to $\mathrm{N}$ alone 
probably relates to the $\mathrm{P}$ status of the nursery and main field. Addition of $\mathrm{N}$ alone may accentuate a P deficiency in nursery seedlings or when they are transplanted into the main field. Certainly P deficiency is very widespread in the rainfed lowland rice soils on which the present studies were conducted [9] [14] [15].

Farmers in Cambodia supply up to two-thirds of their cow manure to their nursery [16], resulting in cow manure addition to nurseries at rates 5 - 10 times higher than in main fields [4]. The present results, suggest that farmers' decisions to apply cow manure preferentially on their nurseries are soundly based. However, the present study shows that cow manure alone, at rates greater than most farmers use, will not achieve maximum growth of seedlings in the nursery. Moreover, farmers' old nurseries still contain very low levels of N, P and K and, in their unfertilised state, remain deficient in several elements for seedling growth [4]. At least N+P need to be applied to nursery soils to increase vigor of transplanted seedlings, and although there may also be a case for $\mathrm{K}$ and $\mathrm{S}$ addition on some soils [15] this was not investigated in the present study.

Part of the increase in grain yield due to fertilizer application to the nursery can be ascribed to the early vigor of the seedlings in the nursery as indicated by greater plant height, increased leaf number, increased tiller number in 9 week-old seedlings, and greater shoot and root dry matter of the fertilised 4, 6 and 9 WAS seedlings. Seedlings with increased vigour may recover faster following transplanting in the rainfed lowlands.

In this experiment, up to $8 \%$ of unfertilised transplanted seedlings died after a 7-day period of submergence. Longer periods of submergence are not infrequent in the rainfed lowlands of Cambodia [6], and may therefore have more severe effects on plant survival than recorded here. Plant height (tallness) is one of the important characteristics for evaluating the submergence tolerance of rice by plant breeders. The taller the plant is, the greater the submergence tolerance capacity is [17]. Tall plants may, therefore, cope better with submergence when it occurs during the post-transplanting recovery growth in large areas of the rainfed lowlands, especially in Cambodia but also in Laos and Thailand [1]. When the leaves are completely submerged, oxygen transport to roots fails, causing impairment of root function including respiration, nutrient uptake and nutrient selectivity [18]. Thus, the simple trait of greater height, which was increased by fertilizer applied to the nursery, may be sufficient to increase survival of seedlings when temporary submergence occurs after transplanting. However, in those places where flash-flooding is common such as in Cambodia, tall rice cultivars are likely to be better adapted than short ones [19].

A strong relationship between nutrient ( $\mathrm{N}$ and $\mathrm{P}$ ) content of seedlings and nutrient content of shoots at PI and in the grain (Figure 3) supports the previous findings that nutrient content in the seedling at transplanting relates
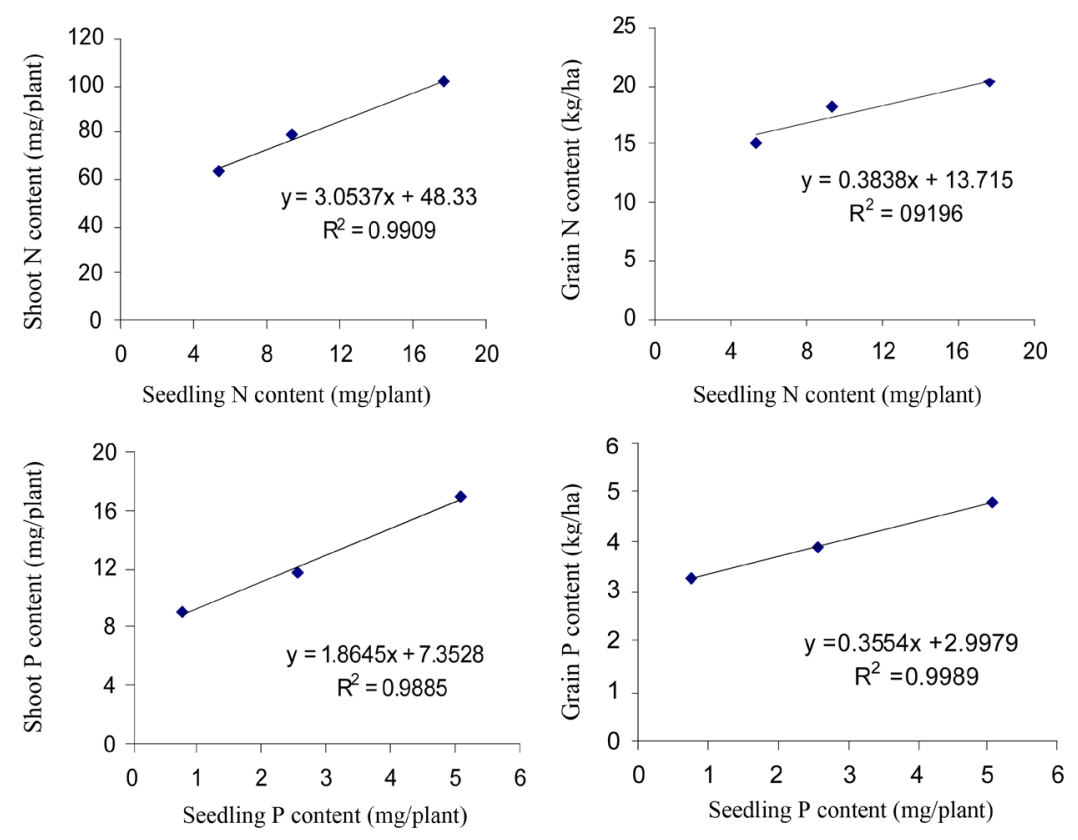

Figure 3. Relationship between $\mathrm{N}$ and $\mathrm{P}$ content of seedlings at pulling and $\mathrm{N}$ and $\mathrm{P}$ content of shoots at panicle initiation and of grain at maturity. Values are means for nursery fertiliser treatments, pooled across main field treatments. Experiment 1. 
to the plant's subsequent growth and final grain yield [5] [18]. However, the increased post-transplanting shoot growth, and eventually grain yield was not simply the direct consequence of the increased nutrient content in shoots of transplanted seedlings. At PI, shoots contained 6 - 12 times as much as $\mathrm{N}$ and 3 - 8 times as much P as transplanted seedlings. Grain contained over a thirty-fold more N and P than transplanted seedlings. The nutrient content in the seedlings at transplanting was only a small proportion of final nutrient content at maturity. Hence the extra nutrient content of fertilised seedlings at transplanting must have acted to accelerate the recovery of seedlings after transplanting, and increase the size of the root and shoot system after transplanting so that plants make more effective use of soil nutrient supply, and tolerate stress factors like nutrient deficiency, drought or submergence. Until clearer definition of the mechanism for the fertilizer stimulation of post-transplanting growth is achieved, it seems reasonable to categorise the response to nursery fertilizer application as a seedling vigor effect. Indeed, in our previous study, a range of treatments (root pruning, leaf clipping, temporary submergence), that depressed seedling vigour impaired post transplanting growth [3]. Decreases in seedling vigour can be induced through nutrient as well as non-nutrient treatments, but the common effect appears to be suppressed recovery after transplanting, with persistent effects including lower grain yield.

Various levels of vigor in the seedlings were created in this experiment by using seedlings with different ages. Six week-old seedlings were more vigorous than younger seedlings in terms of dry matter and stem stiffness. They better withstood submergence soon after transplanting than the 4 WAS seedlings (Table 3; Figure 1). The ability of the plant to withstand complete submergence increases with age [20]. The poorer growth of the 4 WAS seedlings compared to the 6 WAS seedlings even though submergence was more severe in the latter case might be related to plant age. The risk of submergence is particularly pertinent to the promotion in the rainfed lowlands of rice productions systems such as SRI which transplant seedlings at only 8 - 12 days age [21] [22]. While there is evidence of greater tillering and grain yield from transplanting the very young seedlings used in SRI, this is likely to be a risky strategy for the submergence-prone rainfed lowlands.

Larger but older seedlings ( 9 WAS) produced less grain yield than the younger seedlings (4 and 6 WAS). The depression in yield may be due to the shortening of the growth period in the main field caused by delaying transplanting (Figure 2) [23] [24] although the lower nutrient concentrations and greater leaf chlorosis of these seedlings at transplanting may be partly responsible. Under the 21 days shortened growth period, plants transplanted at 9 WAS were apparently less efficient in nutrient uptake even when the main field was fertilised as reflected in lower shoot dry weight at PI and straw nutrient concentrations at maturity. This also supports the previous findings by many workers who have suggested that seedlings as young as 3 - 4 weeks old produced better growth and higher grain yields [24] [25] and contained higher nutrient concentration than aged seedlings [22]. In a recent review [26], optimal seedling age for transplanted rice yield from a number of studies ranged from 25 to 45 days.

Water regimes in the main field had minimal effects on growth of plants in this study apart from those related to submergence which was discussed above. Flooding of all plots after transplanting of seedlings at 4 and 6 WAS made it difficult to impose a clear water stress treatment in the main field. Indeed in the early stages, the drained water plots had adequate standing water levels and the water adequate plots became severely flooded. Water regime, therefore, had little or no effect on plant dry matter before PI except for 4 and 9 week-old seedlings transplanted into main fields without NPK. Water stress periods occurring at or soon after transplanting may be less limiting to post-transplanting growth of fertilised seedlings with the capacity to establish a larger root system. By contrast, the inhibition of plant growth by water drainage after PI was evident in the main field not fertilised with NPK, but not in those fertilised with NPK. Response of rice yield to transplanting the older seedlings (40 vs. 20 days) in Nepal, was accentuated in a drought year compared to the following year with non-limiting water availability [7]. Further study of the effect of an earlier and more severe water stress on the response of rice to nursery fertilizer is warranted since rainfed lowland rice often experiences such periods of water stress.

In summary, the results suggest that supplying $\mathrm{N}$ and $\mathrm{P}$ fertilizers in both the nursery and the main field, and transplanting at 6 WAS, offer good prospects for increased yields of rice in the low fertility, submergence- and drought-prone rainfed lowland soils that are common in South and Southeast Asia. The hypothesis that nursery fertilizer application increases the stress tolerance of seedlings post-transplanting was only partially supported since it increased plant survival due to temporary submergence. Nutrient stress in the main fields induced by not supplying NPK lessened rather than strengthened the responsiveness of plants to nursery fertilizer application. This suggests that the benefit of fertilizer application to the nursery is not due to increased nutrient content of the 
transplanted seedlings per se, but rather an indirect response to increased seedling vigor.

\section{Acknowledgements}

The authors are grateful to the Australian International Agency for Development for a scholarship to the senior author and for funding support provided through the International Rice Research Institute.

\section{References}

[1] Wade, L.J., Fukai, S., Samson, B.K., Ali, A. and Mazid, M.A. (1999) Rainfed Lowland Rice: Physical Environment and Cultivar Requirements. Field Crops Research, 64, 3-12. http://dx.doi.org/10.1016/S0378-4290(99)00047-7

[2] Bell, R.W. and Seng, V. (2004) Rainfed Lowland Rice-Growing Soils of Cambodia, Laos, and Northeast Thailand. In: Seng, V., Craswell, E., Fukai, S. and Fischer, K., Eds., Water in Agriculture. ACIAR Proceedings, 116, 161-173.

[3] Ros, C., Bell, R.W. and White, P.F. (2003) Seedling Vigour and the Early Growth of Transplanted Rice (Oryza sativa). Plant and Soil, 252, 325-337. http://dx.doi.org/10.1023/A:1024736104668

[4] Ros, C., White, P.F. and Bell, R.W. (1998) Field Survey on Nursery and Mainfield Fertilizer Management. Cambodian Journal of Agriculture, 1, 22-33.

[5] Ros, C., Bell, R.W. and White, P.F. (1997) Nursery Applications of N and P Increase Rice (Oryza sativa) Yield. Kasetsart Journal: Natural Science, 31, 96-105.

[6] Javier, E. (1997) Rice Ecosystems and Varieties. In: Nesbitt, H. J., Ed., Rice Production in Cambodia, International Rice Research Institute, Los Banos, 39-82.

[7] Adhikari, B.B., Mehera, B. and Haefele, S. (2013) Impact of Rice Nursery Nutrient Management, Seeding Density and Seedling Age on Yield and Yield Attributes. American Journal Plant Sciences, 4, 146-155. http://dx.doi.org/10.4236/ajps.2013.412a3017

[8] Sarwa, N., Maqsood, M., Wajid, S.A. and Anwar-ul-Haq, M. (2011) Impact of Nursery Seeding Density, Nitrogen, and Seedling Age on Yield and Yield Attributes of Fine Rice. Chilean Journal of Agricultural Science, 71, 343-349. http://dx.doi.org/10.4067/S0718-58392011000300001

[9] White, P.F., Oberthür, T. and Pheav, S. (1997) The Soils Used for Rice Production in Cambodia. A Manual for their Identification and Management. International Rice Research Institute, Los Baños, 70.

[10] Gomez, K.A., Bartolome, V.I., Calinga, R.T. and Cosico, A.B. (1994) IRRISTAT User’s Manual. Version 3. International Rice Research Institute, Los Banos.

[11] Shalaby, Y.Y., Kobbia, T.E. and Omar, M.A. (1969) Rice Yield as Influenced by N-Fertilization in Nursery. Journal of Soil Science of the United Arab Republic, 9, 185-199.

[12] Rajagopalan, S. and Krishnarajan, J. (1987) Effect of Nursery Management Technique on Phosphorus Nutrition of Rice in Main Field. Oryza, 24, 199-209.

[13] Panda, M.M., Reddy, M.D. and Sharma, A.R. (1991) Yield Performance of Rainfed Lowland Rice as Affected by Nursery Fertilization under Conditions of Intermediate Deepwater $(15-50 \mathrm{~cm})$ and Flash Floods. Plant and Soil, 132, 65-71. http://dx.doi.org/10.1007/BF00011013

[14] White, P.F., Nesbitt, H.J., Ros, C., Seng, V. and Pheav, S. (1995) Granulation and Formulation of Local Rock Phosphate Deposits: a Potential Boon for Cambodia. Agro-Chemicals News in Brief, ESCAP/FAO/UNIDO, 18, 26-31.

[15] Seng, V., Ros, C., Bell, R.W., White, P.F. and Hin, S. (2001) Nutrient Requirements for Lowland Rice in Cambodia. In: Fukai, S. and Basnayake, J, Eds., Increased Lowland Rice Production in the Mekong Region, Proceedings of an International Workshop, Vientiane, 30 October-1 November 2000, ACIAR, Canberra, 169-178.

[16] Lando, R.P. and Mak, S. (1994) Rainfed Lowland Rice in Cambodia: A Baseline Survey. IRRI Research Paper Series, No. 152, International Rice Research Institute, Los Banos.

[17] Adkins, S.W., Shiraishi, T. and McComb, J.A. (1990) Submergence Tolerance of Rice-A New Glasshouse Method for the Experimental Submergence of Plants. Physiologia Plantarum, 80, 642-646. http://dx.doi.org/10.1111/j.1399-3054.1990.tb05691.x

[18] Matsuo, T., Kumazawa, K., Ishii, R., Ishihara, K. and Hirata, H. (1995) Science of the Rice Plant. Vol 2. Physiology. Food and Agricultural Policy Research Center, Tokyo.

[19] Ismail, A.M., Johnson, D.E., Ella, E.S., Vergara, G.V. and Baltazar, A.M. (2012) Adaptation to Flooding during Emergence and Seedling Growth in rice And Weeds, and Implications for Crop Establishment. AoB Plants, 2012, pls019. http://dx.doi.org/10.1093/aobpla/pls019

[20] Palada, M.C. and Vergara, B.S. (1972) Environmental Effects on the Resistance of Rice Seedlings to Complete Sub- 
mergence. Crop Science, 12, 209-212. http://dx.doi.org/10.2135/cropsci1972.0011183X001200020018x

[21] Randriamiharisoa, R., Barison, J. and Uphoff, N. (2006) Soil Biological Contributions to the System of Rice Intensification. In: Uphoff, N., Ball, A.S., Fernades, E., Herren, H., Huson, O., Ling, M., Palm, C., Pretty, J., Sanchaez, P., Sanginga, N. and Thies, J., Eds., Biological Approaches to Sustainable Soil Systems, CRC Press, Taylor and Francis Group, Boca Raton, 409-424.

[22] Mandal, B.K. and Ray, P.K. (1984) Effect of Age of Seedlings and Nitrogen Levels on the Growth and Yield of Mahsuri. Indian Journal of Plant Physiology, 27, 303-306.

[23] Basnayake, J., Fukai, S., Sipaseuth, Schiller, J.M. and Monthathip, C. (2006) Advances in Agronomic Research in the Lowland Rice Environments of Laos. In: Schiller, J.M., Chanphengsay, M.B., Linquist, B. and AppaRao, S., Eds., Rice in Laos, International Rice Research Institute, Los Banos, 349-369.

[24] Singh, D.N. and Bhattacharya, A. (1975) Effect of Age of Seedling at Transplanting on Growth and Yield of Rice Varieties (Oryza sativa). Experimental Agriculture, 11, 65-74. http://dx.doi.org/10.1017/S0014479700006244

[25] Patel, C.L., Patel, R.B., Patel, Z.G. and Patel, H.C. (1983) Response of Rice (Var. Mahsuri) to Age of Seedlings at Transplanting, Methods of Transplanting and Depth of Planting. GAU Research Journal, 8, 55-57.

[26] Rajendran, K. and Ganesa raja, V. (2014) Effect of Age of Seedlings on Growth and Yield of Rice. Indian Journal of Advances in Plant Research, 1, 62-66. 